\title{
THE RELATIONSHIP BETWEEN CLINICAL SYMPTOMS AND ULTRASONOGRAPHIC SIGNS IN GOUT
}

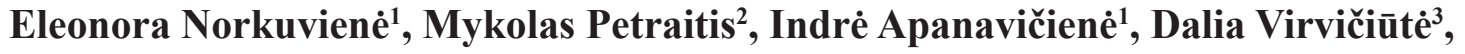 \\ Asta Baranauskaité ${ }^{1}$ \\ ${ }^{1}$ Rheumatology Department, Lithuanian University of Health Sciences, Lithuania, \\ ${ }^{2}$ Rheumatology Department, Hospital of Lithuanian University of Health Sciences Kauno Clinic's, \\ Lithuania, \\ ${ }^{3}$ Institute of Cardiology, Lithuanian University of Health Sciences, Lithuania
}

Key words: gout, ultrasound, concordance, gout attack, tophus.

\begin{abstract}
Summary
For the first time, the new ACR/EULAR gout classification criteria incorporate ultrasound (US) evidence of double contour sign (DC), an articular cartilage abnormality related to the deposition of crystals on the surface of the hyaline cartilage, as a sign specific to gout. US recently has been used as an objective diagnostic tool for detecting urate deposition (tophus (T), DC) or joint damage (erosion) in gout.

Objective: Our aim was to investigate the relationship between clinical gout activity and load of US changes, also to examine the concordance between patient reported joint attack (PRGA) and ultrasonographic intraarticular changes.

Methods: Sixty monosodium-urate-crystal-confirmed gout patients and 36 healthy controls were prospectively included in one centre. The relationship between clinical symptoms and ultrasonographic gout-related changes investigating 36 joints and 4 tendons ( $\mathrm{m}$. triceps and patellar) was evaluated using Spearman's correlation and agreement analysis (kappa coefficient).

Results: moderate, positive correlation was observed between the number of subcutaneous tophi and total US tophus area $(\mathrm{rs}=0,628)$, total number of DC $(\mathrm{rs}=0,612)$, and erosions $(\mathrm{rs}=0,526)$, all $\mathrm{p}<0,0001$, found per patient on US. Gout attacks and disease duration significantly positively correlated with the load of all investigated US changes $(p<0,01)$. Investigating 1980 joints in 55 gout patients irres-
\end{abstract}

pective of treatment and disease duration, symptoms were reported in $307(15,5 \%)$ joints while ultrasound detected signs of urate deposition and erosions in $416(20,9 \%)$ and $143(7,2 \%)$ joints, respectively. The overall concordance rate with PRGA in the joint was fair for tophus $(\kappa=0,333)$, especially in the wrist and ankle, also fair for DC $(\kappa=0,275)$ and erosion $(\kappa=0,217)$. There was large number of clinically false negative joints with $\mathrm{T}$ and/or DC found on US, but also negative intraarticular US in patient-reported arthritis. Better concordance, considered as moderate between PRGA and any sign of urate deposition (US T or DC) was found, investigating 1008 joints in untreated (28) gout subgroup $(\kappa=$ $0,498)$ compared to treated $(\kappa=0,231)$. The specificity of US T, DC, and erosion was $81 \%(\mathrm{p}<0,0001)$, $86 \%(\mathrm{p}<0,0001)$, and $70 \%(\mathrm{p}<0,01)$, respectively. Conclusions: Ultrasonographic changes positively correlate with disease activity and duration in gout with fair to moderate concordance between patientreported gout attack and intraarticular US findings. Not only symptomatic joints should be used for US gout classification in clinical practice.

\section{Introduction}

The golden standard for gout diagnosis is the demonstration of negatively birefringent, needle-shaped monosodium urate crystals in the synovial fluid [1]. However, obtaining synovial fluid requires training and operator comfort, so most primary care or emergency room doctors choose clinical judgement instead of joint aspiration [1, 2]. Clinical signs, such as the number of gout attacks per year, the total number of gout attacks per life, and clinically detectable tophi are considered as markers of dise- 
ase severity, according to which the decision for hypouricemic treatment for many years has been made $[3,4]$. The use of non-invasive radiologic diagnostic techniques, such as high-resolution ultrasound or dual-energy CT (DECT) for gout diagnosis, incorporated into the recent $2015 \mathrm{ACR} /$ EULAR gout classification criteria [5] let us visualise the MSU crystal deposits, as well as measure the total body urate burden in the joints and periarticular structures $[6,7]$. High-resolution ultrasound (US) was shown to be more sensitive than conventional radiography in revealing joint damage - joint erosions - in gout [8]. US might be a tool for measuring the response to therapy in gout $[9,10]$. Relying on that, gout experts at the OMERACT 9 gout workshop stated that the number of gout attacks, the physical measurement of subcutaneous tophi (T), in combination with US assessment of intraarticular T may contribute to a definition of remission in patients with gout [11]. But there is a lack of studies investigating the relationship between the clinical symptoms and spread of US findings in gout. The studies with asymptomatic hyperuricemia $[12,13]$ or gout studies investigating both: the symptomatic and the contralateral joint [14] showed that $\mathrm{T}$, double contour (DC), and even erosions (E) can be found in the joint, in which symptoms have never been reported, raising the question of concordance between the clinics and US changes. Which joints should be investigated for gout classification, just the symptomatic joints or more, independently of symptoms, this is still a matter of discussion.

Our goal was to determine if there is a relationship between the clinical severity of gout and US urate load or joint damage visible on ultrasound, also to determine how big the concordance is between patient reported gout attack and intraarticular ultrasonographic findings.

\section{Methods}

Selection of patients. The analysis was done within a case-control study conducted in 2014-2016 in one centre designed for investigation of sensitivity and specificity of US in gout, which prospectively included adult gout patients (60) attending a tertiary rheumatology unit during intercritical gout stage independently of disease duration and treatment and healthy normouricemic controls (36) as a comparator group. Gout diagnosis was confirmed by MSU crystal detection in synovial fluid from symptomatic ever joint or bursa under polarised light microscopy independently by two study investigators - rheumatologists (EN and IA) in all cases. The sensitivity and specificity of intraarticular US T, DC, and erosion according controls was estimated to be $85 \%$ and $83 \%(p<0,0001), 87 \%$ and $86 \%$ $(\mathrm{p}<0,0001), 63 \%$ and $70 \%(\mathrm{p}=0,003)$, respectively. To eli- minate the potential impact of hypouricemic treatment to the sensitivity of US [9, 10], some statistical analysis in this study was done excluding patients treated with hypouricemic drugs. Only patients capable to recall the sites of gout attacks were selected for concordance analysis between the clinical joint involvement and US signs of urate deposition.

The study was approved by the Lithuanian University of Health Sciences Kaunas Region Biomedical Research Ethics Committee. Written informed consent was obtained from all subjects before study entry.

Laboratory and clinical investigation. All patients underwent blood sampling for CRP, creatinine, and serum uric acid (SUA), also clinical investigation, done by a qualified rheumatologist (EN). Height, weight, and subcutaneous tophi were recorded. A detailed disease history was taken of gout symptom duration, number of gout attacks per life/ per last year and joints with gout attacks, reported by patient were recorded in a special form or on homunculus, when suitable. The gout attack was described as a sudden onset of painful joint swelling, with maximum inflammation developing within one day and clearing within one to two weeks [3]. The number of gout attacks per life was counted as follows: exact number of gout attacks reported by patient during the first two years of disease plus medium number of attacks per year multiplied by years with symptoms in patients with disease duration more than two years.

Ultrasonographic assesment. Standardised US examination of 36 joints (both wrists, metacarpophalangeal (MCP), hand proximal interphalangeal (PIP), knees, ankles and metatarsophalangeals (MTPs)) and 2 tendons (m. triceps and patellar) was performed in a darkened room for all participants at the same day as clinical investigation by other rheumatologist (MP), with high experience (more than 10 years) in musculosceletal US, blinded to clinical data. The LOGIQ e US system with a $12 \mathrm{MHz}$ linear transducer on B mode scale was used for US examination. All joints were scanned in the longitudinal plane dorsal side. Knees were explored on longitudinal and transversal planes in suprapatellar and parapatellar joint recesses on full extension of the leg for joint cavity evaluation, longitudinally in 20 degrees flexion for patellar tendon evaluation and transversally in maximal flexion to analyse femoral cartilage. The ankles were investigated on longitudinal plane dorsal and lateral sides. The views were chosen as per guidelines for musculoskeletal US [15-17]. Joints were investigated for the presence of DC, T and erosion. The US T was defined as circumscribed heterogeneous hyperechoic / isoechoic (relative to subdermal fat) sometimes with hypoechoic inclusions mass with or without small anechoic rim; the DC sign was defined as hyperechoic band over the super- 


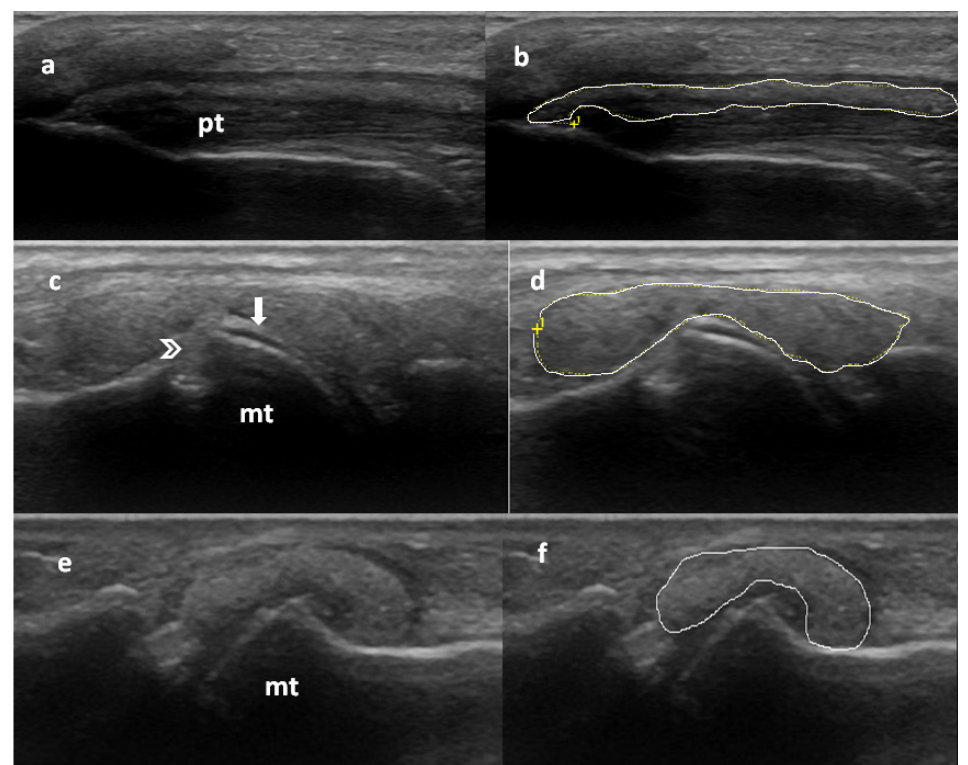

substantial and $>0,80$ almost perfect reliability [20]. The correlation between variables was determined using Spearman's correlation coefficient (rs). P values less than 0,05 were considered significant.

\section{Results}

In all, 60 patients with gout were used for correlation analysis between clinical symptoms and US features. Fifty-five from them were able to report the symptomatic joints and were used for concordance analysis between patient reported gout attack and US. Twenty-eight patients were not using hypouricemic treatment. Table 1 . shows the demographic and clinical characteristics of the participants (Table 1).

The total number of intraarticular $\mathrm{T}$, periarticular T, total T, total DC, and total E found per patient on ultrasound ranged from $0-26,0-4,0-30$,

Figure 1. Ultrasonographic changes in gout: a,b longitudinal ultrasound (US) image of upper part of patellar tendon, revealing hyperechoic tophus - like masses, changing the normal course of tendon fibers; $c-f$ longitudinal US images of metatarsophalangeal joints with nonhomogeneous isoechoic $(\mathrm{c}, \mathrm{d})$ or hyperechoic $(\mathrm{e}, \mathrm{f})$ intraarticular tophus-like masses with $(\mathrm{e}, \mathrm{f})$ and without $(\mathrm{c}, \mathrm{d})$ hypoechoic rim, double contour sign (arrow) and erosion ( arrow head). Tracing around the outline of the tophus shows tophus area (b, d, f); pt, patellar; mt, metatarsal bone.

ficial margin of the articular hyaline cartilage, visible independent of the angle of insonation $[6,9,10,15,18]$; Erosion was defined as an intra- and /or extra-articular discontinuity of the bone surface (visible in two perpendicular planes) [15] The size of $T$ was measured as the area of nodulus, considered to be US tophus, calculated by continuous tracing around the outline of the nodulus and calculating the area enclosed within the outline, measured using the integrated software in the US machine [19] (figure 1).

Statistical analysis. Statistical analysis was performed using SPSS statistical software version 20.0 SPSS, Chicago, Illinois, USA. The study sample was described as mean $\pm \mathrm{SD}$ or median for continuous variables and frequency (\%) for categorical variables. Concordance between intraarticular B-US findings and patient reported joints with previous gout symptoms, was done using unweighted Cohen's $\kappa$ - statistics in terms of dichotomous assessment (i.e. presence or absence) and interpreted as follows: $0-0,20$ represent slight; 0,21-0,40 fair; 0,41-0,60 moderate; 0,61-0,80 $0-29$, and $0-18$, respectively. Total US T count moderately positively correlated with erosions and DC detected on US per patient with $r s=0,605$ and $r s=0,646$, respectively (all

Table 1. Patient characteristics

$U L T$ - urate lowering therapy; BMI - body mass index, GFR-glomerular filtration rate; UA - Uric acid concentration; NA- not applicable.

\begin{tabular}{|l|c|c|c|}
\hline & $\begin{array}{c}\text { Gout group } \\
\text { N60 }\end{array}$ & $\begin{array}{c}\text { Gout group } \\
\text { N55 }\end{array}$ & $\begin{array}{c}\text { Treatment } \\
\text { naïve gout } \\
\text { N28 }\end{array}$ \\
\hline Gender (male/female) & $52 / 8$ & $48 / 8$ & $25 / 3$ \\
\hline Age, y mean(SD) & $53,77(11,1)$ & $55,18(10,4)$ & $54,1(10,6)$ \\
\hline $\begin{array}{l}\text { Serum uric acid, } \\
\mu \text { mol/1, mean(SD) }\end{array}$ & $498,57(135,1)$ & $493,6(138,6)$ & $529,75(137,2)$ \\
\hline $\begin{array}{l}\text { GFR (mL/min), } \\
\text { mean(SD) }\end{array}$ & $102,93(42,7)$ & $104,8(40,8)$ & $101,0(42,5)$ \\
\hline \begin{tabular}{l} 
CRP $(\mathrm{mg} / \mathrm{l})(\mathrm{mean})(\mathrm{SD})$ \\
\hline $\begin{array}{l}\text { BMI }\left(\mathrm{kg} / \mathrm{m}^{2}\right) \\
\text { mean(SD) }\end{array}$
\end{tabular} & $15,2(16,4)$ & $15,2(17)$ & $14,2(16,1)$ \\
\hline \begin{tabular}{l} 
ULT use, $\mathrm{n}(\%)$ \\
\hline $\begin{array}{l}\text { UA }<360 \mu \text { mol/1, } \mathrm{n} \\
(\%)\end{array}$
\end{tabular} & $21(35,0)$ & $21(38,2)$ & $31,28(5,1)$ \\
\hline $\begin{array}{l}\text { Gout symptoms dura- } \\
\text { tion, y median }\end{array}$ & $3(0,1-33)$ & $4(0,1-33)$ & $4(0,1-33)$ \\
\hline $\begin{array}{l}\text { Symptom duration } \leq 2 \\
\text { years, } \mathrm{n}(\%)\end{array}$ & $25(41)$ & $20(36,4)$ & $12(43)$ \\
\hline $\begin{array}{l}\text { Gout attacks per last } \\
\text { year, } \mathrm{n} \text { median }\end{array}$ & $3,5(1-104)$ & $4(1-104)$ & $2,5(1-104)$ \\
\hline $\begin{array}{l}\text { Gout attacks per life, } \mathrm{n} \\
\text { median }\end{array}$ & $8(1-860)$ & $8(1-860)$ & $8(1-500)$ \\
\hline $\begin{array}{l}\text { Subcutaneous Tophus, } \\
\mathrm{n}(\%)\end{array}$ & $24(40)$ & $24(43,6)$ & $5(17,9)$ \\
\hline
\end{tabular}


$\mathrm{p}<0,0001)$.

There was positive moderate correlation between the disease duration and amount of all investigated US changes: $\mathrm{T}$ ( $\mathrm{rs}=0,582), \mathrm{DC}(\mathrm{rs}=0,532)$, and $\mathrm{E}(\mathrm{rs}=0,481)$ (all $\mathrm{p}<0,0001$ ), found per patient.

Correlation between US findings and clinical signs of disease activity, reported by patient. The number of acute attacks per year/per life had a significant positive correlation with the total number of intraarticular $\mathrm{T}$ $(r s=0,518 / 0,652 ; p<0,0001)$, intraarticular and periarticu-

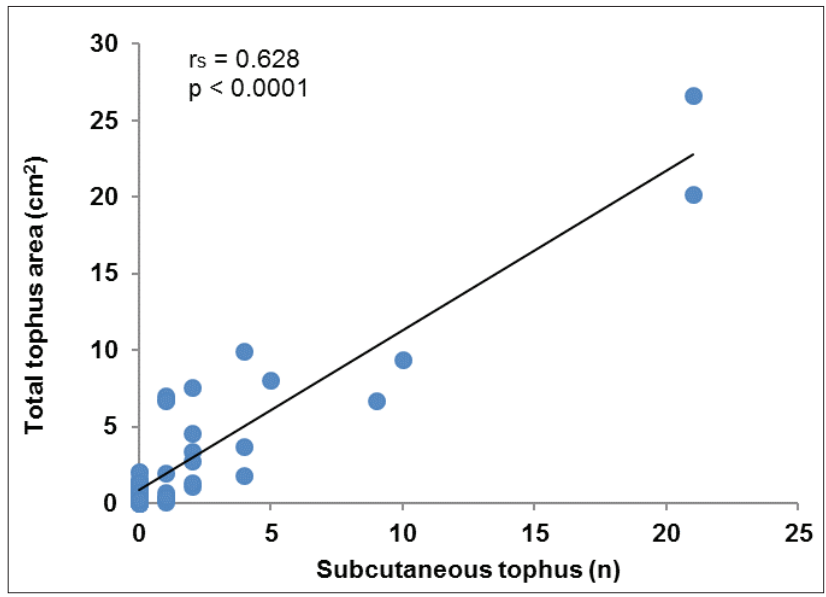

Figure 2. Correlation between the number of subcutaneous tophus detected on clinical examination and total tophus area, estimated by ultrasound, assessing thirty six joints and four tendons per patient in gout.

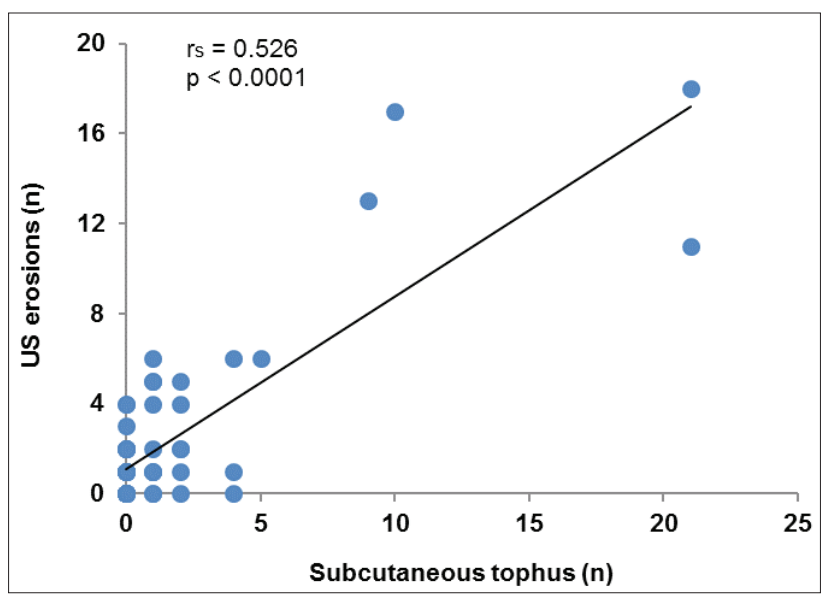

Figure 3. Correlation between the number of subcutaneous tophus detected on clinical examination and total number of erosions, estimated by ultrasound, assessing thirty six joints per patient in gout. lar T (rs =0,552 / 0,699; $\mathrm{p}<0,0001), \mathrm{DC}(\mathrm{rs}=0,374$ / 0,551; $\mathrm{p}<0,01)$, erosions $(\mathrm{rs}=0,374 / 0,542 ; \mathrm{p}<0,01)$, and the total tophus area $(\mathrm{rs}=0,420 / 0,549 ; \mathrm{p}<0,01)$ measured on US per patient.

There was positive correlation between the total number of joints with gout attacks reported by patients with intraarticular $\mathrm{T}$, periarticular $\mathrm{T}$, total $\mathrm{T}$, total $\mathrm{DC}$, and total intraarticular $\mathrm{E}$ found per patient on US with $\mathrm{rs}=0,459$, $r s=0,515, r s=0,555, r s=0,509$ and $r s=0,325$, respectively with all $\mathrm{p}<0,001$.

Correlation between US findings and subcutaneous tophus, detected by rheumatologist. There was a positive correlation between the number of subcutaneous tophus found on clinical examination and the total number of tophus ( $\mathrm{rs}=0,600)$, total tophus area $(\mathrm{rs}=0,628)$ (figure 2$)$, $\mathrm{DC}(\mathrm{rs}=0,612)$ and erosion $(\mathrm{rs}=0,526)$ (figure 3 ) detected on US (all $p<0,0001$ ). The clinically visible tophi correlated with the disease duration ( $\mathrm{rs}=0,718 ; \mathrm{p}<0,0001)$, the number of gout attacks per year $(\mathrm{rs}=0,514 ; \mathrm{p}<0,0001)$ and gout attacks per life ( $r s=0,752 ; p<0,0001)$ (Figure 1,2).

Correlation between US findings and uric acid concentration and CRP. There was no correlation between CRP and US changes: number of tophus ( $\mathrm{rs}=0,141$, $\mathrm{p}=0,286), \mathrm{DC}(\mathrm{rs}=0,220, \mathrm{p}=0,093)$ or erosion $(\mathrm{rs}=0,100$, $\mathrm{p}=0,450$ ) found per patient. CRP positively correlated with the total number of joints with gout attacks reported by patient $(\mathrm{rs}=0,394 ; \mathrm{p}<0,01)$. There was no correlation between the uric acid concentration and US changes: total number of T ( $r s=0,193, p=0,139), D C(r s=0,179, p=0,170)$ or $\mathrm{E}(\mathrm{rs}=0,063, \mathrm{p}=0,634)$ found per patient in the whole (60) gout group; also no correlation in untreated (28) patient group.

Table 2. Concordance ( $\kappa$ value) between ultrasound (US) T, DC sign, erosion and patient reported symptoms in the joint of gout participants irrespective of hypouricemic treatment.

\begin{tabular}{|l|c|c|c|}
\hline & & $\begin{array}{c}\text { Total } \\
(\mathbf{n = 1 9 8 0})\end{array}$ & $\begin{array}{c}\text { Early gout } \\
(\mathbf{N}=\mathbf{7 2 0})\end{array}$ \\
\hline $\begin{array}{l}\text { Patient reported } \\
\text { gout flares }\end{array}$ & $\%$ & 15.5 & 7.4 \\
& & & \\
& K vs. & 0.333 & 0.426 \\
& US T & 0.270 & 0.203 \\
& USDC & 0.378 & 0.400 \\
& UST/ DC & 0.217 & 0.200 \\
\hline US E & $\%$ & 20.9 & 8.8 \\
\hline US T/DC & $\%$ & 12.0 & 5.3 \\
\hline US DC & $\%$ & 12.6 & 4.9 \\
\hline US E & $\%$ & 7.2 & 2.4 \\
\hline
\end{tabular}


Table 3. Concordance ( $\kappa$ value) between ultrasound (US) T, DC sign, erosion and clinical findings in the joints of hipouricemic treatment-naïve gout participants (28).

Data given as \% of joints positive for : patient- reported symptoms of gout flare; and US tophus (T), double contour (DC), US tophus and double contour (UST/DC) or erosion (E) found on US examination. Concordance with US lesions given as $\kappa$ values. PIP, proximal interphalangeal joint; MCP, metacarpophalangeal joint; MTP metatarsophalangeal joint; $n d-$ evaluation not done.

\begin{tabular}{|l|c|c|c|c|c|c|c|c|}
\hline & & PIP+MCP & Wrist & Knee & Ankle & MTP I & $\begin{array}{c}\text { MTP } \\
\text { II-V } \\
(\mathbf{n = 2 2 4})\end{array}$ & Total \\
$\mathbf{( n = 1 0 0 8})$
\end{tabular}

The concordance between intraarticular ultrasonographic gout changes and patient-reported gout attack. The strength of agreement between patient-reported gout attack and US signs of intraarticular urate deposition (US T, DC), also damage (erosion) was fair in heterogeneous according treatment group of 55 gout patients with US being up to 1.3 times more sensitive according signs of urate deposition but revealing 2.2 times fewer intraarticular erosions than clinical signs (table 2). Data in the table 2 are given as $\%$ of joints positive for : patient - reported symptoms of gout flare and US tophus (T) or double contour (DC) found on US examination. Concordance with

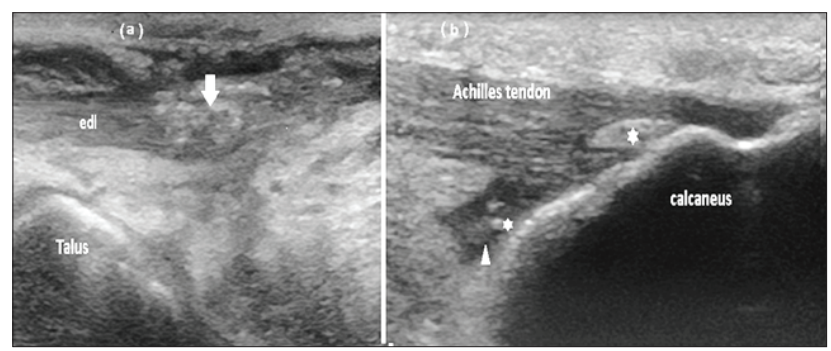

Figure 4. Ankle ultrasound (US): periarticular involvement in a case of periodical ankle swelling in gout.

a. Longitudinal scan of extensor digitorum longus tendon (edl) widening due to tendinosis and intratendinous hyperechogenic nonhomogeneous tophus-like masses (arrows), changing the normal course of the tendon fibers.

b. Longitudinal scan of achilles tendon with hyperechoic mass at the insertion to the calcaneus (star) and retrocalcaneus bursitis (arrow head) with hyperechoic spots (star), supposed to be urate deposits.
US lesions given as $\kappa$ values. PIP, proximal interphalan- geal joint; MCP, metacarpophalangeal joint; MTP metatar- sophalangeal joint.

Moderate agreement $(\kappa=$ 0,498 ) between clinical symptoms and any sign of urate deposition inside the joint space was found upon investigating 1008 joints in the untreated gout subgroup (28) (table 3), compared to fair $(\kappa=$ 0,231 ) in untreated group, independently of symptom duration.

US in general (group 28) was 1.5 times more sensitive than clinical symptoms with the biggest gap in the II-V metatarsophalangeal joints, revealing 6.4 times more signs of intraarticular urate deposition compared to patient's reports. The results in knee and ankle joints were the opposite - patients reported 1.3 times more symptoms compared to intraarticular US signs of urate deposition. The frequency of gout attacks in the joints with US signs of urate deposition is presented in the table 4 .

\section{Discussion}

In this study we investigated the relationship between the subjective and objective signs of clinical disease activity and the burden of US changes in gout, investigating 36 joints and 4 tendons. It was the first attempt systemically to check the link between patient reported gout attacks and intraarticular ultrasonographic changes using multiple-joint investigation in gout.

We found a significant, mostly moderate [21] positive correlation between the patient reported number of gout attacks per year/per life, the number of subcutaneous tophi found by a rheumatologist per patient, and load of ultrasonographic signs of urate deposition. Clinical disease activity (objective and subjective symptoms) positively correlated with the joint damage - number of erosions found per patient on US. Gout-related US signs significantly moderately positively correlated with each other. These findings confirm the hypothesis that gout symptom severity and joint damage increases with the load of urate deposition in joints or periarticular tissues that is visible on ultrasound. Our study suggests that clinically visible subcutaneous tophi could be a prognostic marker of the magnitude of joint damage in gout. This is in agreement 
Table 4. Link between ultrasonographic gout-specific findings in the joint and gout attack in hypouricemic treatment-naïve gout participants (28), investigating 1008 joints.

T, tophus; DC, double contour sign; E, erosion

\begin{tabular}{|l|c|l|c|c|}
\hline & T & DC & $\begin{array}{l}\text { T and/or } \\
\text { DC }\end{array}$ & E \\
\hline $\begin{array}{l}\text { Joints with } \\
\text { US findings, } \mathrm{n}\end{array}$ & 88 & 111 & 159 & 35 \\
\hline Gout attack + & 46 & 55 & 74 & 18 \\
\hline Gout attack - & 42 & 56 & 85 & 17 \\
\hline
\end{tabular}

with Rajan's et al., study [22] which found the relationship between clinics and changes on dual-energy computed tomography (DECT) where urate volume correlated with the subcutaneous tophus count ( $\mathrm{rs}=0,62, \mathrm{p}<0,0001)$, swollen joint count ( $r s=0,32, p=0,007)$, and flare frequency ( $r s=$ $0,26, p=0,03$ ). The correlation between erosion and tophus area $(r s=0,510)$ or tophus number $(r s=0,646)$ was bigger than that with patient reported number of symptomatic joints ( $r s=0,325)$, suggesting the tophus as being a bigger predictor for damage than clinical symptoms, which is also in agreement with other US studies showing the relationship between the tophus and erosion in the joint [23]. We did not find the correlation between CRP and total tophus area measured on US which was different from the previously mentioned Rajan et al., study [22] which reported a correlation between urate volume and $\mathrm{C}$ reactive protein ( $\mathrm{rs}=0,36, \mathrm{p}=0,002)$, but in agreement with Rajan et al., study according no relationship between uric acid and US changes, which could be explained by the fact that only $15 \%$ of our patients had uric acid concentration less than $360 \mathrm{mkmol} / \mathrm{l}$ - the expected therapeutic goal in gout treatment [4].

Investigating 1980 joints in 55 gout patients irrespecti- ve of treatment and disease duration, we found that concor- dance between patient reported gout attack in the joint and intraarticular US findings was fair with $\kappa=0,333$, 0,275 , and 0,217 for tophus, DC, and erosion, respectively. There was a large number of clinically false negative joints with $\mathrm{T}$ and/or DC found on US (mostly radiocarpal, metatar- sophalangeal joints, indicating higher sensitivity of US in these cases, but also negative intraarticular US in symptomatic joints (mostly knees and ankles). The explanation for this could be periarticular involvement in some "arthritis" cases: figure 4 represents a case of intermittent gout attack in the ankle joint, as reported per patient, with no US changes in the anterior recess of the tibiotalar joint, but with periarticular US involvement.

Tophi in the patellar tendon (figure 1) visible on US could potentially cause swelling in the knee area and be dismissed by the patient as an "attack of arthritis". Frequent periarticular involvement is described in previous ultrasounds [6], also DECT studies: DECT helped to diagnose gout in 11 out of 30 patients with undifferentiated arthritis/ tendinitis/enthesitis who had a negative synovial fluid-polarising microscopy from their initial diagnostic evaluation; periarticular involvement was shown on DECT in these cases [24]. Another reason of disagreement between clinical symptoms and US in the knee area found in our study might be low sensitivity of US regarding $\mathrm{T}$ in suprapatellar and parapatellar joint recesses. Perez-Ruiz et al. reported tophi lying deep in the inner collateral ligament in the knee joint, the area not evaluated in our study [9]. Better agreement, considered as moderate between PRGA and any sign of urate deposition (US T or DC) was found, investigating 1008 joints in untreated (28) or 720 joints in early (20) gout patients, with $\kappa=0,498$ and $\kappa=0,400$, respectively, indicating a potential impact of hypouricemic treatment to the sensitivity of US or some possible bias towards patients not recalling an attack properly in late gout. So we should not rely on just "symptomatic" joint investigation for US gout classification during intercritical gout stage, especially in advanced disease.

Our study has some weaknesses such as the crosssectional design for the evaluation of the relationship between clinical symptoms and US, also the absence of other high- sensitivity imaging such as MRI or DECT [23, 26]. Nevertheless we checked the specificity of US using control group. There is still a need for longitudinal studies to confirm the relationship between clinics and US, also to confirm US tophi and DC as an outcome measure for gout.

\section{Conclusions}

Ultrasonographic changes positively correlate with subjective and objective signs of disease activity and disease duration in gout with fair to moderate concordance between patient-reported gout attack and intraarticular US findings. Not only symptomatic joint should be used for US gout classification in clinical practice.

\section{References}

1. Taylor WJ, Fransen J, Jansen TL, Dalbeth N, Schumacher HR, Brown M. et al. Study for updated gout classification criteria: identification of features to classify gout. Arthritis Care Res (Hoboken) [Internet]. 2015 Sep 1 [cited 2016 Nov 22];67(9):1304-15. Available from: http://onlinelibrary.wiley. com/doi/10.1002/acr.22585/full

2. Kissin EY, Pillinger MH. The Sound and the Fury: Musculoskeletal ultrasound in the diagnosis of gout. Arthritis Rheumatol 
(Hoboken, NJ) [Internet]. 2016 Oct 16 [cited 2017 Jan 2]; Available from: http://www.ncbi.nlm.nih.gov/pubmed/27748075

3. Zhang W, Doherty M, Bardin T, Pascual E, Barskova V, Conaghan P. et al. EULAR evidence based recommendations for gout. Part II: Management. Report of a task force of the EULAR Standing Committee For International Clinical Studies Including Therapeutics (ESCISIT). Ann Rheum Dis [Internet]. 2006 Oct 1;65(10):1312-24. Available from: http://ard.bmj. com/content $/ 65 / 10 / 1312$.abstract

https://doi.org/10.1136/ard.2006.055269

4. Richette P, Doherty M, Pascual E, Barskova V, Becce F, Castaeda-Sanabria J. et al. 2016 updated EULAR evidence-based recommendations for the management of gout. Ann Rheum Dis [Internet]. 2017 Jan 1;76(1):29-42. Available from: http://ard. bmj.com/content/76/1/29.abstract

https://doi.org/10.1136/annrheumdis-2016-209707

5. Neogi T, Jansen TLT a, Dalbeth N, Fransen J, Schumacher HR, Berendsen D. et al. 2015 Gout classification criteria: an American College of Rheumatology/European League Against Rheumatism collaborative initiative. Ann Rheum Dis [Internet]. 2015;74(10):1789-98. Available from: http://ard.bmj.com/ lookup/doi/10.1136/annrheumdis-2015-208237

6. Naredo E, Uson J, Jiménez-Palop M, Martínez A, Vicente E, Brito E. et al. Ultrasound-detected musculoskeletal urate crystal deposition: which joints and what findings should be assessed for diagnosing gout? Ann Rheum Dis [Internet]. 2013;1-7.

7. Huppertz A, Hermann K-G a, Diekhoff T, Wagner M, Hamm B, Schmidt W a. Systemic staging for urate crystal deposits with dual-energy CT and ultrasound in patients with suspected gout. Rheumatol Int [Internet]. 2014;34(6):763-71. Available from: http://www.ncbi.nlm.nih.gov/pubmed/2461956 https://doi.org/10.1007/s00296-014-2979-1

8. Schlesinger N, Thiele RG. The pathogenesis of bone erosions in gouty arthritis. Ann Rheum Dis [Internet]. 2010 Nov 1 [cited 2017 Jan 23];69(11):1907-12. Available from: http://ard.bmj. com/cgi/content/short/69/11/1907

9. Perez-Ruiz F, Martin I, Canteli B. Ultrasonographic measurement of tophi as an outcome measure for chronic gout. J Rheumatol 2007;34(9):1888-93.

10. Ottaviani S, Gill G, Aubrun A, Palazzo E, Meyer O, Dieudé P. Ultrasound in gout: a useful tool for following urate-lowering therapy. Joint Bone Spine [Internet]. 2015 Jan [cited 2016 Jan 29];82(1):42-4. Available from: http://www.sciencedirect.com/ science/article/pii/S1297319X1400089X

11. Grainger R, Taylor WJ, Dalbeth N, Perez-Ruiz F, Singh JA, Waltrip RW. et al. Progress in measurement instruments for acute and chronic gout studies. J Rheumatol [Internet]. 2009 Oct 1;36(10):2346-55. Available from: http://www.jrheum.org/ content/36/10/2346.abstract

https://doi.org/10.3899/jrheum.090371

12. Pineda C, Amezcua-Guerra LM, Solano C, RodriguezHenríquez P, Hernández-Díaz C, Vargas A. et al. Joint and tendon subclinical involvement suggestive of gouty arthritis in asymptomatic hyperuricemia: an ultrasound controlled study. Arthritis Res Ther [Internet]. BioMed Central; 2011 Jan 17;13(1):R4. Available from: http://www.ncbi.nlm.nih.gov/ pmc/articles/PMC3241349/

13. Stewart S, Dalbeth N, Vandal AC, Allen B, Miranda R, Rome K. Ultrasound features of the first metatarsophalangeal joint in gout and asymptomatic hyperuricaemia: comparison with normouricaemic individuals. Arthritis Care Res [Internet]. 2016 Sep 1;n/a-n/a. Available from: http://dx.doi.org/10.1002/ acr.23082

https://doi.org/10.1002/acr.23082

14. Wright SA, Filippucci E, McVeigh C, Grey A, McCarron M, Grassi W. et al. High-resolution ultrasonography of the first metatarsal phalangeal joint in gout: a controlled study. Ann Rheum Dis [Internet]. 2007;66(7):859-64. Available from: http://ard.bmj.com/content/66/7/859\%5Cnhttp://www.ncbi. nlm.nih.gov/pubmed/17185326

https://doi.org/10.1136/ard.2006.062802

15. Backhaus M, Burmester GR, Gerber T, Grassi W, Machold KP, Swen WA. et al. Guidelines for musculoskeletal ultrasound in rheumatology. Ann Rheum Dis [Internet]. $2001 \mathrm{Jul}$ 1;60(7):641-9. Available from: http://www.pubmedcentral.nih. gov/articlerender.fcgi?artid=1753749\&tool=pmcentrez\&rend ertype $=$ abstract

https://doi.org/10.1136/ard.60.7.641

16. Filippucci E, Meenagh G, Delle Sedie A, Sakellariou G, Iagnocco A, Riente L. et al. Ultrasound imaging for the rheumatologist XXXVI. Sonographic assessment of the foot in gout patients. Clin Exp Rheumatol 2011; 29(6):901-5.

17. Filippucci E, Scire CA, Delle Sedie A, Iagnocco A, Riente L, Meenagh G. et al. Ultrasound imaging for the rheumatologist. XXV. Sonographic assessment of the knee in patients with gout and calcium pyrophosphate deposition disease. Clin Exp Rheumatol 2010; 28(1):2-5.

18. Dalbeth N, Doyle AJ. Imaging of gout: an overview. Best pract res clin rheumatol [Internet]. 2012;26(6):823-38. Available from: http://www.ncbi.nlm.nih.gov/pubmed/23273794 https://doi.org/10.1016/j.berh.2012.09.003

19. Hobson-Webb LD, Massey JM, Juel VC, Sanders DB. The ultrasonographic wrist-to-forearm median nerve area ratio in carpal tunnel syndrome. Clin Neurophysiol 2008 Jun;119(6):1353-7. Available from: http://www.sciencedirect. com/science/article/pii/S1388245708001430 https://doi.org/10.1016/j.clinph.2008.01.101

20. Barnhart HX, Yow E, Crowley AL, Daubert MA, Rabineau D, Bigelow R. et al. Choice of agreement indices for assessing and improving measurement reproducibility in a core laboratory setting. [Internet]. Statistical methods in medical research. 2014. p. 0962280214534651-. Available from: http://smm.sagepub.com/content/early/2014/05/14/0962280214534651.long

21. Mukaka MM. A guide to appropriate use of Correlation coefficient in medical research. Malawi Med J [Internet]. Malawi: The Medical Association Of Malawi; 2012 Sep;24(3):69-71. 
Available from: http://www.ncbi.nlm.nih.gov/pmc/articles/ PMC3576830/

22. Rajan A, Aati O, Kalluru R, Gamble GD, Horne A, Doyle AJ, et al. Lack of change in urate deposition by dual-energy computed tomography among clinically stable patients with long-standing tophaceous gout: a prospective longitudinal study. Arthritis Res Ther [Internet]. BioMed Central; 2013 Oct 23;15(5):R160-R160. Available from: http://www.ncbi.nlm. nih.gov/pmc/articles/PMC3978645/

23. Bongartz T, Glazebrook KN, Kavros SJ, Murthy NS, Merry SP, Franz WB, et al. Dual-energy CT for the diagnosis of gout: an accuracy and diagnostic yield study. Ann Rheum Dis [Internet]. BMA House, Tavistock Square, London, WC1H 9JR: BMJ Publishing Group; 2015 Jun 26;74(6):1072-7. Available from: http://ard.bmj.com.ezproxy.auckland.ac.nz/content/74/6/1072

24. Lamers-Karnebeek FBG, Van Riel PLCM, Jansen TL. Additive value for ultrasonographic signal in a screening algorithm for patients presenting with acute mono-/oligoarthritis in whom gout is suspected. Clin Rheumatol [Internet]. 2014;33(4):555-9. https://doi.org/10.1007/s10067-014-2505-6

25. Ogdie A, Taylor WJ, Neogi T, Fransen J, Jansen TL, Ralph Schumacher H, et al. Performance of Ultrasound in the Diagnosis of Gout in a Multi-Center Study: Comparison with Monosodium Urate Crystal Analysis as the Gold Standard. Arthritis Rheumatol (Hoboken, NJ) [Internet]. 2016 Oct 16 [cited 2016 Nov 22]; Available from: http://www.ncbi.nlm. nih.gov/pubmed/27748084

26. Dalbeth N, Doyle AJ. Imaging of gout: an overview. Best Pract Res Clin Rheumatol 2012;26(6):823-38.

\section{KLINIKINIŲ SIMPTOMU巳 IR ULTRAGARSINIŲ POŽYMIU RYŠYS SERGANT PODAGRA}

\section{E. Norkuvienė, M. Petraitis, I. Apanavičienė, D. Virvičiūtė,}

\section{A. Baranauskaitė}

Raktažodžiai: podagra, ultragarsas, sutapimas, podagros priepuolis, tofusas.

Santrauka

2015 metų Europos ir Amerikos Reumatologų Asociacijų paruoštas podagros diagnostikos algoritmas įtraukẻ ultragarsą (UG) kaip specifinị metodą, galintị padèti diagnozuoti podagrą. UG leidžia objektyviai įvertinti uratų sankaupas (tofuso (T) arba dvigubo kontūro požymis (DK) sąnariuose bei aplink sąnarị esančiuose audiniuose, nustatyti sąnario destrukcijos požymius-erozijas.
Darbo tikslas - nustatyti, kaip klinikiniai podagros simptomai koreliuoja su ultragarsiniais podagros požymiais bei įvertinti artrito priepuolio anamnezèje ir UG pokyčių sąnario artmėje ryšį.

Metodai. Atliktas prospektyvinis vieno centro tyrimas, kuriame dalyvavo šešiasdešimt auksiniu diagnostikos standartu patvirtintų podagra sergančiųjų bei trisdešimt šeši sveiki kontroliniai su normalia šlapimo rūgšties koncentracija kraujyje asmenys. Ryšiui tarp klinikinių simptomų ir ultragarsu nustatomų podagrai būdingu požymių (tiriant 36 sąnarius bei 4 sausgysles) nustatyti buvo naudojama Spearman'o koreliacija bei sutapimo analizè, taikant Koheno Kappa kriterijų (,unweighted Cohen's Kappa“).

Rezultatai. Nustatytas vidutinio stiprumo teigiamas tarpusavio ryšys tarp kliniškai matomų poodinių tofusų skaičiaus bei bendro UG išmatuoto tofusų ploto ( $\mathrm{rs}=0,628)$, DK $(\mathrm{rs}=0,612)$ ir erozijų $(\mathrm{rs}=0,526)$ skaičiaus vienam pacientui, nustatomų UG (visais atvejais $\mathrm{p}<0,0001$ ). Podagros priepuolių skaičius bei ligos trukmė reikšmingai teigiamai koreliavo su visų tirtų UG požymių paplitimu $(\mathrm{p}<0,01)$. Heterogeniškoje pagal skiriamą gydymą bei ligos trukmę 55 pacientų grupeje, tiriant 1980 sąnarius, simptomai pasireiškè $307(15,5 \%)$, tuo tarpu UG uratų sankaupos ir erozijos rastos atitinkamai $416(20,9 \%)$ ir 143 (7,2\%) sąnariuose. Apskritai ryšys tarp podagros priepuolio sąnaryje ir UG radinių buvo silpnas: UG T $\kappa=$ 0,333 , UG DK $\kappa=0,275$ ir erozijos $\kappa=0,217$. Rasta daug kliniškai besimptomių sąnarių, kuriuose nustatyti intrasąnariniai tofusai ir/ ar dvigubo kontūro požymiai (riešo, metatarsofalanginiai sąnariai), bet buvo nemažai ir simptominių sąnarių, kuriuose nerasta intrasąnarinių UG podagros požymių. Didesnis sutapimas tarp simptomų ir UG uratų sankaupų (T ir/arba DK) stebėtas tiriant 1008 sąnarius negydytos podagros $(28)$ pogrupyje $(\kappa=0,498)$ lyginant su gydytais asmenimis $(\kappa=0,231)$. UG tofuso, DK ir erozijos specifiškumas, lyginant su kontroliniais asmenimis, nustatytas atitinkamai $81 \%$ $(\mathrm{p}, 0,0001), 86 \%(\mathrm{p}<0,0001)$ ir $70 \%(\mathrm{p}<0,01)$.

Išvados. Esant ryškesniems podagros simptomams ir ilgesnei ligos trukmei ultragarsu nustatoma daugiau podagrai specifinių požymių, tačiau ryšys tarp ultragarsinio tyrimo radinių ir priepuolio sąnaryje, remiantis paciento anamneze, buvo mažas ar vidutiniškas. Ultragarsinis tyrimas papildo klinikinius duomenis, todèl ne tik simptominiai sąnariai turètų būti tiriami siekiant diagnozuoti podagrą klinikinèje praktikoje.

Adresas susirašinèti: levutei@yahoo.com

Gauta 2017-02-03 